\title{
3
}

\section{The expansion of Europe: Vienna 1857}

T

he year 1857 was the last carefree year of the Austrian Empire, geographically the second largest state in Europe after Russia. Its territory stretched from Bregenz and Milan in the west to Braşov and Lviv in the east, from Prague in the north to Dalmatia on the Adriatic Sea. The colossal multi-ethnic empire had many enemies, inside and outside its borders. Rising nationalism was a threat to domestic stability, and neighbouring powers were waiting for an opportunity to profit from the internal tensions. In 1858, emperor Napoleon III and Piedmontese statesman Camillo Benso di Cavour met in Plombières, where they agreed that France would support Piedmont (or rather the kingdom of Sardinia) in its goal of liberating the Italian peninsula from Austrian domination. The agreement strengthened Piedmont's self-confidence and led to a war in the spring of 1859 between Austria and the northern Italian kingdom. The Austrian army suffered crushing defeats at Magenta and Solferino. At the Conference of Villafranca, emperor Franz Joseph I was forced to cede Lombardy to the kingdom of Sardinia, an act which set off the formation of the Italian state. Austria's defeat cost it dearly. In 1866, it was compelled to surrender Venice to Italy, too. The proud Habsburg monarchy thus began a long descent that would end in the total collapse of the empire in 1918.

But the end of the empire was unthinkable in 1857. The Austrian ruling class lived in another world: not in Stefan Zweig's 'world of yesterday' but in an even older world. Admittedly, the revolution of 1848 had undermined the power of the Habsburgs, but the accession of Franz Joseph in the same year and the cautious politics of Prime Minister Felix zu Schwarzenberg and his successors re-established the empire among Europe's great powers. Austria was an obvious choice to host the third international statistical congress. The government was eager to enhance its international standing by demonstrating its ability to facilitate cooperation between the state and science. 
Under the inspired leadership of Karl von Czoernig, statistics quickly became a valued service in the administrative apparatus of the monarchy. The rapid rise of statistics was linked to the political course Austria took in the years after 1850. The emperor and the government intended to halt democratic reforms and saw statistics as a source of reliable, neutral knowledge that transcended the promises of the political and nationalist opposition movements. In practice, statistics was also an effective instrument of government which offered a partial solution to the language problem. Like German, statistics was an efficient means of communication between administrative levels within the empire, a transnational language that did not appear to favour any one ethnic group. It was in the interests of the central government in Vienna to perfect this language.

Some of the statisticians at the Paris congress of 1855 called for the next gathering to be held in the German-speaking region of Europe, though Britain had explicitly volunteered to host the next event. As a Prussian, Dieterici kept a low profile during the decision making (the French preparatory commission had the final say), but he agreed that the organisation should move to a German city. In Germany, he reasoned in his usual anti-French manner, more attention would be given to the scientific basis of statistics as a matter of course, without administrative and legislative issues coming into play. By the time Vienna was chosen, though, Dieterici had lost all interest in the matter, which left Prussia in the remarkable position of having no official delegate to the congress in 1857. The good news was that the great and ancient powers of Russia and Turkey would be sending representatives for the first time. Expectations were running high.

\section{Karl von Czoernig and his mission}

Karl von Czoernig, the director of government statistics in Austria, had made a big impression at the congresses in Brussels and Paris, not least on Leopold von Ranke, who characterised him as someone who lives entirely in the present, strong and resolute, with a broad world view. ${ }^{1}$ Czoernig was a man of many talents. Besides being a statistician, he was also a creative artist. In 1856 he painted Ansicht des Dachsteins, a work that ended up in the collection of the Louvain town hall in 1879 through the agency of Xavier Heuschling, Quetelet's right hand. ${ }^{2}$ Czoernig, born in Tschernhausen (Černousy) in 1804, near Liberec (then Reichenberg) in North Bohemia, studied law in Prague and Vienna and developed a passion for political science and statistics early in life. His first individual publication was a historical statistical study in the eighteenth-century German tradition of 'state description', Topografisch-historisch-statistische Beschreibung von Reichenberg (Vienna 1829). In 1828 he joined the civil service. He was first stationed in Trieste, and from 1831 in Milan, where he served as secretary ('Präsidialsekretär') to the governor of Lombardy from 1834. His statistical work continued to attract attention while he was in Italy. In 1841 he was appointed director of 'administrative statistics' and transferred to Vienna. 
In 1848 Czoernig was elected to the liberal Frankfurt Parliament by the inhabitants of his native district, without his cooperation (or so it says in his obituary of 1889). ${ }^{3}$ This so-called 'parliament of professors' counted other statisticians among its members, such as Friedrich Wilhelm Freiherr von Reden, co-founder of the Zeitschrift des Vereins für deutsche Statistik, and Johannes Fallati, author of Einleitung in die Wissenschaft der Statistik (Tübingen 1843). Czoernig was a member of the right-leaning liberal majority, which supported a constitutional monarchy and a federal political structure. He was unable - and unwilling - to accomplish much in Frankfurt. After the success of the Kleindeutschland movement, the failure of the Vienna Revolution and the adoption of the 'chartered' constitution of March 1849, he returned to Vienna for good. Czoernig was appointed to a high office in the Ministry of Trade, where he had oversight of official statistics and carried out a series of special projects. He was dispatched to Trieste to reorganise the central shipping agency and, for a while, he managed the state railway service. In 1852 he set up a commission for the study and preservation of Austrian monuments, which he chaired for over ten years. In 1854 he was sent on a mission to the major banking houses in the capitals of Europe, including Amsterdam, to negotiate large loans for the Austrian state, which was perennially short of cash.

Czoernig was above all a technocrat and felt comfortable with the bureaucracy of the neo-absolutist monarchy of Franz Joseph. After the liberal revolution in Austria failed, the emperor rejected parliamentary experimentation. He relied on strong military bureaucratic power and staked everything on economic modernisation, investing heavily in the railways. In 1857, the year of the statistical congress, Czoernig published the second volume of his major work Ethnographie der österreichischen Monarchie (Vienna 1855, 1857), which dealt with Austria's government reforms from 1848. A year later Cotta in Stuttgart published the volume with a new foreword under the title Oesterreich's Neugestaltung 1848-1858. It was a eulogy to the state and bureaucracy. He dutifully wrote that the emperor was the source of unity in the Habsburg Empire. He underlined the role of the Reichsrat, an advisory council to the emperor, which the constitution of March 1849 had introduced as a counterweight to parliament and the council of ministers. With the 'Sylvesterpatent' and retraction of the constitution on 31 December 1851 the Reichsrat was the only remaining political check on the emperor's power, but in fact it was virtually ineffective as such. The centralised bureaucracy - in combination with the army - was the instrument by which the emperor governed; but the bureaucracy also steered and influenced imperial power more than any other political body. Czoernig saw that and could live with it. Moreover, he had little interest in political reform, as long as the mechanism of the state was able to operate effectively and efficiently. Austrian 'Neugestaltung', or reorganisation, was in his view primarily a matter of 'good administration'.

Statistics offered Czoernig many excellent opportunities to put his ideas concerning public administration into practice. In 1841, when he was made director of government statistics, the agency was in need of a complete overhaul. 
Since 1829 there had been a statistical bureau at the General-RechnungsDirektorium, a kind of court of audit responsible for examining government expenditure. Before 1829 statistics in Austria consisted of incidental population censuses and private monographs in the tradition of eighteenth-century political science. In 1827 professor Joseph Rohrer of Lemberg (Lviv) published a Statistik des österreichischen Kaiserthums, claiming he had gathered the material for his work during his travels around the empire, which he had paid for himself. In other countries, Austrian statistics were considered to be unreliable and cloaked in secrecy. Wilhelm Ludwig Volz, a high official in the Grand Duchy of Baden and expert on German statistics, did not mince words when, after touring the region, he wrote that of all the German states Austria produced the worst statistics; even the population censuses were extremely inaccurate. $\mathrm{He}$ claimed that Vienna knew nothing about Hungary, Galicia or Transylvania. ${ }^{4}$ This was probably an exaggeration, but it was true that in comparison to French and Belgian statistics, Austria's did not amount to much until Czoernig appeared on the scene. The state had neither assumed responsibility for organising systematic statistical research, nor permitted statistics to play a role of any significance in the public domain.

The civil servants who manned the statistical bureau founded in 1829 were primarily accountants. Emperor Francis I had consented to its establishment under the limiting condition that 'no new personnel or increases would be derived from it; no controversial surveys would be commissioned; and finally completed statistics would not be disclosed to authorities or persons who were not entitled to be informed of them by virtue of their position. ${ }^{5}$ Czoernig was disappointed. The idea behind the development of a new imperial department of statistics (k.k. Direktion der administrativen Statistik) in 1840 was to give government statistics a more authoritative role, and Czoernig was just the man to do it. The new agency would inject uniformity and comprehensiveness into the process of obtaining and processing statistical information about the empire. In addition, the information would be made universally accessible.

Czoernig applied himself to the completion and publication of the Tafeln zur Statistik derösterreichischen Monarchie, which had been produced in small print runs for internal government use since 1829. Initially, these statistical tables were secret and only the highest-ranking officials in Vienna and the provincial governors had access to them. One hundred copies were printed of the first edition, six of which were intended for the Court. The Court's copies were more lavish than the others, which emphasised the exclusive nature of the series. They featured a copper-engraved title page, a reproduction of a watercolour by Thomas Ender depicting Vienna as seen from the countryside surrounding the city, and a series of financial tables which were apparently intended for use by only the highest-ranking individuals. When Czoernig took charge of government statistics, the tables were made more widely available for general official use; only the financial and military data remained classified. In 1848, the year of revolution, the combined volumes of the 1845 and 1846 Tafeln, including the previously classified parts, were published in full. This act of decensorship did 
not benefit the public directly, however. The tables were published in folio and were expensive, but at least they could be viewed at libraries and exchanged for foreign statistical publications.

After his statistics department moved to the Ministry of Trade in 1848, Czoernig began publishing the Mittheilungen über Handel, Gewerbe und Verkehrsmittel sowie aus dem Gebiete der Statistik (issued monthly from 1850, quarterly from 1852 and under the abridged title Mittheilungen aus dem Gebiete der Statistik). The aim of the report was in essence the same as that of the daily newspaper Austria published under the auspices of Czoernig's department in 1849: to present current economic numbers and infrastructural data.

In his opening address at the statistical congress of 1857, Czoernig justified his publications and his efforts to reform the statistics agency:

But the improvements in the work of the administrative statistics department would have been of little use if, as in accordance with custom, only the smallest circle of officials had been permitted to make use of it; because if a scientific achievement is not exposed to the light of day, there is a danger that it may fossilise or fade; and it is not just statesmen who feel the urge and the need to stay abreast of national statistics. The entire educated public is interested in public affairs and a very large number of businessmen participate directly in economic life. ${ }^{6}$

Czoernig wanted producers to provide him with data on industry and agriculture directly and knew that he would have to give them something in return. Publication was meant to encourage precision.

Czoernig's statistics project was first and foremost a practical undertaking intended to streamline administrative processes. Public disclosure of the data was a sincere aim in itself, but it ultimately served the interests of the state. Citizens, especially educated ones, were entitled to have access to information about the power of the state and, as a result, gain a true sense of their citizenship. Entrepreneurs needed access to key economic data. Political rights, however, were of minor importance. When Czoernig was ennobled in 1852 and given the title Freiherr von Czernhausen, he had his coat of arms engraved with Bacon's words 'Wissen ist Macht'. This was Czoernig's scientific and political creed.

Czoernig firmly believed in the Austrian Gesamtstaat. His Bohemian origins and bureaucratic career in Northern Italy sowed the seeds of his conviction that many peoples could live together under a single emperor, even without political concessions. The constitution of 1849 had granted equal status to all nationalities living within the borders of the empire, but the Sylvesterpatent of 1851, which cut political liberalism off at the pass, left few of these rights intact. Domestic policy was aimed at fully depoliticising nationalist aspirations. Czoernig made an interesting contribution to this endeavour. His Ethnographie der österreichischen Monarchie and the accompanying ethnographic map were an unprecedentedly accurate, empirical description of the 'Vielvölkerstaat'. It was based on the population census of 1851, but presented little numerical data. The work was steeped in the German tradition of descriptive statistics, but also 
attempted to breathe new life into that tradition.

'Staatenkunde' (political science), the predecessor of descriptive statistics, had incorporated geographical and topographical descriptions since the eighteenth century. Professor August Ludwig von Schlözer of Göttingen, a renowned champion of government statistics, was already using the terms 'Völkerkunde' (ethnology) and 'Ethnographie' (ethnography) in 1771, and developing methods of drawing comparisons between peoples and societies. Josef Mader, a professor of history and political science in Prague, mentioned ethnology explicitly in his Materialien zur alten und neuen Statistik von Böhmen (Prague 1787). Czoernig was sufficiently knowledgeable about topographical statistics from his earlier work and education, but his descriptive account of the monarchy was more than an ethnographic study. In the same way that the Frenchman Guillard introduced 'demography' as the core concept of statistics, and scrutinised demographic developments in France in order to truly understand them, Czoernig proposed that ethnography be employed as an auxiliary science to statistics in order to give the nationality issue in the Austrian empire a scientific dimension and to offer solutions based on science rather than political rights. His aspiration did not go unnoticed. Emperor Franz Joseph took a personal interest in Czoernig's ethnography and kept a copy in his private library.

Czoernig's objective was to find a historical justification for an 'empire' that did not want to be, and could not be, a 'nation. His ethnographic description was so detailed that it defied every large-scale ethno-nationalist claim: the Austrian monarchy comprised nearly 150 geo-administrative units, 22 language communities and four large ethnic groups (Germans, Slavs, Romans and 'Asian tribes'). Amid such diversity, neither autonomy nor popular sovereignty was an option. One glance at the map and it was obvious that the empire was a historically constituted multi-ethnic state whose right to exist lay in the hereditary monarchy and in the anti-nationalist 'ethnographic element', in which neither language nor population size was of overriding importance. Hungarian nationalism, Italian nationalism and every other nationalism that existed within the borders of the empire were, in Czoernig's view, merely fads without any true cultural-historical basis.

In Oesterreich's Neugestaltung Czoernig used the Italian example to illustrate his point. He believed that the peninsula was geographically unsuitable for establishing a unitary state. Moreover, there was enormous 'racial diversity' in Italy, which could be traced back to pre-Roman times and was still recognisable. The Italian language, he continued, was not spoken by the people. With all these differences, the Italians would be better off abandoning nationalism, because 'still today, once the thin veneer of polished urban civilization is removed, in customs and traditions, in physique and facial expression the powerful son of the graceful Celtic tribe could never be mistaken for the gentle, southern Trinacrian, so fond of the Oriental emotional life, nor could the mild, well-spoken Venetian, whose Greek origins are still phonetically audible, be confused with the roughly-aspirating, jovial Tuscan or with the Roman, considered the prototype of manly beauty.? The Italian nationalists of Czoernig's time 
entertained, in his view, only subversive plans; their invocation of a national identity masked political self-interest. Whatever benefits they associated with unity, it was clear to Czoernig that Italy had rendered its greatest cultural achievements in a time of geopolitical fragmentation.

Implicit in this was a justification of the Habsburg Empire, which was trying to preserve itself in a time of rising nationalism. The paradox of Czoernig's ethnographic statistical study is that it strengthened the ethnic identity of the peoples he described, which in turn stirred their desire for autonomy. Like statistics, ethnography was open to interpretation, and could serve highly divergent interests. For example, a Hungarian ethnography published in 1876, the year the international statistical congress was held in Budapest, attempted to define the Hungarian people on the basis of a common linguistic history and, in doing so, provide a scientific justification for the Ausgleich of $1867 .{ }^{8}$

\section{Ethnography}

It was no coincidence that Czoernig completed his Ethnographie in 1857 and published part of it separately. His aim was to position himself internationally as an authoritative statistician with a mission. Czoernig was the first to introduce ethnographic statistics in the international arena. Dieterici, still in charge of the Prussian bureau in 1857, was unable to muster any enthusiasm for a third attempt to get international statistics off the ground. He would turn 67 shortly before the Vienna congress and was no longer interested in adventure. In his report on the Paris congress he had complained about the lack of scientific interest among the participants. He did not believe that ethnic diversity in the Austrian monarchy would bring any progress to the development of international statistics as he had envisaged it. Furthermore, there was no evidence in his public demeanour or private correspondence to suggest that his scientific aspirations went beyond Prussian interests. In a letter to his minister, he wrote that Czoernig was primarily concerned with practical matters, such as the railways, and like Freiherr von Reden, he had not penetrated the essence of statistics as a science. Dieterici added 'that Vienna, the capital of an empire comprised of multiple nationalities (Germans, Slavs, Hungarians, Italians), would have difficulty unifying the scientific community on statistical matters. ${ }^{9}$ But the Austrian attempted to transform this apparent weakness into a strength by including ethnographic statistics on the congress agenda.

Czoernig defined ethnography as the science 'that studies individual ethnic groups on the basis of their rise and disappearance, their development and decline, their influence on political, social and religious life in the present and in the past, and the characteristics of their language, life, customs and development, examining each one in isolation and in interaction with the other groups with which it comes into contact. ${ }^{10}$ His positioning of ethnography between history and statistics echoes Schlözer's definitions of history as perpetual statistics and statistics as stationary, present-day history. As an auxiliary science to 
the former, ethnography examines the historical development of peoples; as an auxiliary science to the latter, it is concerned with the present-day territorial distribution of peoples.

The congress was not the appropriate place to consider the historical element, but it would no doubt provide fertile ground for ethnographic statistics. Czoernig proposed to design a survey that would address the following 'ethnographic-statistical moments': territorial distribution of the 'races' (the term used in the French translation) within the boundaries of the state, the population of the individual races and size of their territory, and an outline of the primary physical, linguistic and cultural characteristics of each one. Naturally, Czoernig presented his illustrated Austrian ethnography to the congress, pointing out that his experience had taught him that 'the organic characteristics of the ethnographic moment in the society of the peoples of a state frequently emerge if the state unites in itself diverse ethnographic elements and if these elements assume political significance or even decisively affect the structure of public life, the activities of the government and the position of the state in the larger community of states within the civilised world. ${ }^{11}$ The Austrian Empire was proof of this claim. There can be no doubt that Czoernig was specifically addressing Russia and Turkey, which were similar, ethnically divided states. In this sense, the third international statistical congress was broader than the previous two had been in terms of subject matter and participating countries. It served the interests of the organising state, but tried to avoid stirring up nationalist sentiments.

Czoernig's proposal was discussed along with two other matters: the relationship between statistics and the natural sciences, and the use of graphic representation. Apparently Czoernig did not dare to couple ethnography with population censuses on the agenda, a theme that had featured in congress programmes from the very start and had much in common with ethnographic statistics. ${ }^{12}$ For most European states ethnicity was unimportant, but in Austria, Turkey and Russia it was a highly sensitive issue. To the casual observer it might seem that nature and cartography had little to do with ethnographic statistics, but the organising committee felt that the three topics were closely connected. The relationship between statistics and the 'natural sciences' - geography, meteorology, botany, zoology and the like - raised questions concerning the domain of statistics and where its boundaries lay, questions that would remain unanswered in the second half of the century. But what really mattered were the 'physical' subjects considered relevant to public administration. The discussion turned to matters like variations in land elevation, water levels and vegetation, features that could be illustrated on maps in one way or another.

Czoernig strongly advocated using maps in statistical publications and said so in his opening speech. He pointed out that coloured maps, with or without symbols, enabled the reader to see the spatial dimension of the numerical data at a glance. He undoubtedly had his own ethnographic map in mind. Moreover, messages could often be conveyed faster and more clearly using symbols. Reaching international agreement on the symbols used was at least as important 
as international standardisation in numerical statistics. These ideas may seem obvious to us now, but graphic representations and maps were scarce in the statistical works of the day. Dupin's 'education map', discussed in Chapter 2, was imitated in France, but there was absolutely no international standardisation. In his Commercial and Political Atlas of 1786 and in later works, William Playfair had shown examples of 'linear arithmetic', including the coloured diagrams illustrating trade between Britain and North America, but there was no breakthrough in this area during the first half of the nineteenth century. ${ }^{13}$ Given the situation, the discussion at the congress of 1857 might have been an important step, but as it turned out the results were meagre at best. By the time the topic was put on the agenda of The Hague congress in 1869, little progress had been made. The only examples of the graphic method in the congress report of 1857 were two road and river maps and a complicated table on literary production in the crown-lands of the Habsburg state.

Franz Ritter von Hauslab, a field marshal and corresponding member of the Austrian Academy of Sciences, had prepared an impressive report on statistical cartography. His military background betrays the origin of his interest. The cartography department was an important military service, richly endowed with knowledge of graphics methods. The director of the institute of military geography in Vienna, August von Fligély, was a member of the preparatory commission. And it is reasonable to assume that the representatives of the Austrian army (ten were present according to the printed attendance lists) followed this part of the congress with special interest.

Hauslab argued that statistics had three resources at its disposal: numbers, words and symbols. Which of the three was most appropriate depended on the nature of the subject matter. If graphic representation was your instrument of choice, you would need to consider what it was you wanted to represent. Hauslab believed there were nine forms in which statistical data could be depicted: 1) maps showing the specific location of factories, animals, plants and minerals; 2) maps showing regional population densities; 3) graphic representations showing the absolute population number in various regions; 4) incremental graphic representations of water levels and temperature; 5) ethnographic maps; 6) comparative graphic representations of the surface area of different countries; 7) maps showing the relationship between the location of goods production and the places where the goods were sold, consumed or exported; 8) graphic representations of temperature and barometric pressure at different times and in different places; 9) flood maps. Hauslab concluded his list with the apodictic words: 'every graphic representation used for statistical purposes can be classified under one of these nine categories. ${ }^{14}$ It was no more than logical that he considered the statistics of agriculture, industry and transport roads eminently well-suited for conversion into the language of symbols.

The apparent inconsistency of this list demonstrates how little systematic thought went into the graphics methods used in statistics in 1857, in our eyes at least. For many people, series of numbers were difficult enough to understand; graphs and charts posed an even greater challenge. When this issue was 
discussed during the congress, it became clear that when people thought in images they were more likely to envisage maps than graphs or diagrams, preferably in full colour. It was easier to depict the increase and decrease of certain phenomena on a map using colour. Valentin Streffleur, a director at the Ministry of Finance and member of the preparatory commission, came up with a series of three basic colours plus white, and their twelve combinations (e.g. yellow shading on a white background or blue cross-hatching on a red background). Gradations of light and dark could be used to illustrate rankings or changes, such as an increase in industrial output, crops or population.

The statistical maps that were published in the first half of the nineteenth century were primarily geographical maps showing the distribution of a particular phenomenon (e.g. cholera) - in some cases relative to a population figure. People worked mainly with absolute numbers, quantities that were directly related to reality. Proportions and other quantitative relationships were more complicated, especially when they were lifted out of the geographical context.

Ernst Engel, who still represented government statistics in Saxony in 1857 (he would transfer to the Prussian bureau in 1859), expressed doubts about graphic representation. While he acknowledged that there were some benefits to processing absolute numbers in statistical topographical maps, he believed there was absolutely no scientific advantage in comparing quantities, since the relative numbers that resulted from such exercises usually referred to a single relationship, at best depicted by a few steps. Like many of his colleagues, Engel was wary of simplifications. Moreover, colours or other symbols used to designate spatial distribution could easily cause confusion. In his eyes, a wide range of spatial, chronological and practical information could be presented in tables without creating a disorderly impression or oversimplifying matters. ${ }^{15}$ In this light, it is not surprising that the congress was loathe to take any decisions about standards for colours or symbols; the best they could do was to defer the issue to the next congress.

Neither the official Rechenschafts-Bericht of the congress nor the detailed report drawn up by Adolf Ficker, a staff member at the Direktion der administrativen Statistik, mentioned a lively discussion about ethnographic statistics. Someone remarked that studying the characteristics of peoples in the manner Czoernig proposed would not necessarily yield numerical data and therefore this method could not be considered statistical by Quetelet's definition. It would be more useful to study only those characteristics that lent themselves to statistical research, because ethnography would otherwise consist of 'blosse Schilderungen' (mere descriptions) and it would be impossible to calculate the influence of the 'nationality' factor - alongside a range of other factors - on human development. ${ }^{16}$ Nevertheless, Czoernig's proposal was adopted virtually verbatim. Only Austrians had been engaged in this subject and their interest was merely descriptive; the others had no real affinity with it or abstained from expressing an opinion.

The fact that Austrians were overrepresented in the discussion was not solely due to the topic at hand. At any given congress, nationals of the host country 
made up a large majority of the participants. In fact, attendance at every international statistical congress held between 1853 and 1876 was dominated by inhabitants of the organising country. In this respect, the Vienna congress of 1857 was a low point: only 14 per cent of participants came from outside the Habsburg Empire. ${ }^{17}$ For the first time, German was the official language of the congress. In Brussels and Paris it had not occurred to anyone to deviate from the French, the most widely used diplomatic language in Europe. The Austrian preparatory commission decided that the conclusions of the sessions held prior to the plenaries would be presented in both French and German. Participants would be allowed to use either language during the discussion, and if anyone wished to address the congress in a third language (not inconceivable considering the location), that would be possible, provided he was able to submit a written translation of his remarks in one of the main languages. In addition, Czoernig - a polyglot - made sure that in informal situations he addressed people in their own language whenever possible. After the congress, Samuel Brown, who represented the Statistical Society of London, wrote 'nor can the foreign members of the Congress easily forget the courtesy and attentions which they individually received from him during its whole continuance. ${ }^{18}$

\section{Counting money}

Financial statistics was another subject that captured the particular attention of the Austrian government. At the Paris congress there had been calls for more international attention to this matter, and it was not surprising that the Austrians took an interest in expanding on it. It was widely known that the Austrian state had a large budget deficit and was interested in any means - including the statistical - of making matters appear rosier than they probably were.

Besides this concern, which was not openly discussed of course, there were others underlying the extensive nomenclature that the preparatory commission presented for discussion. In the tradition of state descriptions, government revenue and expenditure was a primary theme, though the ancien régime was a stickler for secrecy when it came to this issue. The Austrian government was unaccustomed to justifying its budgets and accounts to the public. It was under no constitutional obligation to do so and, besides, no one was interested in exposing the colossal deficits that kept the treasury under almost constant pressure. During the Restoration and the Vormärz, the Austrian economy had a strong, early modern, decentralised character, which was difficult to control. It was vital to avoid repeating the national bankruptcy of 1811 and even more important to dispel the impression that the imperial court and the government bureaucracy were the main culprits.

Czoernig was one of the few who realised that there were potential advantages to greater transparency. In the first place, disclosure would require the state to have a full understanding of the revenue and spending of all its bodies. 
This was no mean task, given the complexities of the Austrian state apparatus. The reward for the state's efforts in this respect would be the improvement of its ability to conduct audits and obtain credit.

The revolution of 1848 and its outcome were advantageous to Czoernig. Parliamentary control was still out the question, but the state was in favour of economic and bureaucratic modernisation. A financially sophisticated economy was in keeping with this goal. An adequate budget and account would enable the government to better harmonise revenues, investments, tax policy and economic reforms. Not a word was said about a role for parliament. Later Czoernig wrote: 'today there is no better means of assessing a state, its administration and its agencies than by subjecting the budget to a thorough audit. ${ }^{19}$ Again, his interest in financial statistics betrays his technocratic tendencies and his focus on bureaucratic and statistical innovation, rather than on political reform.

Like the Austrian bureaucrats, representatives of the smaller German states were also interested in financial statistics. These states had been part of the Zollverein since 1834 (since 1853 Austria had had an affiliation with the union in the form of a trade agreement with Prussia) and stood to benefit from shared knowledge and uniformity in financial matters. Karl Ritter von Hock, a department head at the finance ministry, introduced the discussion at the congress. $\mathrm{He}$ came to the disheartening conclusion that even if it were possible to categorise all sums of money from every financial account there would still be no solution to the problem of the different origins of the sums. It was virtually impossible to determine for each country what part the state, the local authorities and other institutions had in monetary flows. And even if this problem could somehow be solved, there was the matter of the state's capital and reserves. Data on a state's assets were extremely hard to come by, either for technical reasons (how should the value of a piece of infrastructure be calculated?) or due to rules of secrecy. But Hock was implacable: even if all this information could be obtained, he would also want to know how 'expansible' national incomes were, i.e. what was their growth potential? This seemed a mammoth task for statistics bureaus of the age. For the time being, it would remain impossible to come up with methodological criteria to make a clear distinction between statistics and economics.

Be that as it may, the preparatory commission submitted a detailed financial nomenclature, aimed at generating some progress. This topic was largely debated during the morning sessions of experts and was highly technical and formalistic. The majority of participants were statisticians from the Germanspeaking countries, but occasionally an outsider would speak up. The Dutch liberal economist Simon Vissering, for example, drew the participants' attention to the major significance of colonies for a number of countries and opined that statistics should take this factor into account. No one took the trouble to revisit the proposal in its adapted form during the plenary session. A representative from Baden said he thought Hock's contribution should be published in its entirety in the Wiener Zeitung, so that everyone could study it in their spare 
time. How many might have answered that call?

Austria did not reap the benefits that Czoernig had hoped for. In his comparative financial statistics of 1862, written after Austria had finally begun publishing its annual accounts in 1860 , he admitted that the recommendations of the 1857 congress had yielded little. His Direktion der administrativen Statistik was 'unable to adhere strictly to the regime for financial statistics laid down at the Vienna congress, because the science was insufficiently developed and the public administration bodies were not in a position to furnish the necessary material: ${ }^{20}$ Statistics gained little from the attempts of the congress to acquire a modicum of international insight and the Austrian treasury was unable to profit from the appealing but impractical European statistics programme. Austria's financial situation remained extremely precarious. In 1866 the government seriously considered offering the former Dutch finance minister, Pieter Philip van Bosse, the same portfolio in Austria. ${ }^{21}$

\section{The art of combining}

In addition to finance and ethnography, the main topics of the third international statistical congress were education, industry, mortality, hospitals and nursing homes, criminal and civil law, the allocation of land ownership and rates. The overarching challenge statisticians faced with respect to all these issues was to find a way to learn about and enumerate the profusion of social phenomena without losing sight of the requirements of and limitations inherent in the science of statistics. The thirst for knowledge overwhelmed them time and again, and the illusion persisted that the world could be fully described by statistical means. Paradoxically, this universalist aspiration accentuated the diversity that existed among nations - and the particularities within nations. The Vienna congress produced seemingly endless lists of questions on all these subjects. However, the requisite statistical research was probably not feasible, and even if the raw data could be collected everywhere they would probably be ill-suited to international comparison.

Of course, this is easily said in hindsight. Czoernig told the congress that the merging of statistics and the state would automatically resolve the scientific sticking points: 'From the perspective of statistics, today we require not just a numerical description of various elements of the state as they are at present or were in the recent past, but also evidence - in a usable form - of the causal link between all significant phenomena in political and economic life. ${ }^{.22}$ To Czoernig it was clear as day that government was the only institution that could furnish the data and cohesion.

Czoernig's state was not neutral, however. The rhetoric of efficiency and comprehensiveness shrouded the interests of the conservative Austrian elite: bureaucratic reform and economic modernisation, but no new political freedoms. Yet it was not just established state interests that determined statistical themes and methodologies. The nomenclature of causes of death, for 
example, was first and foremost a medical matter, but medical science was far from being able to furnish a universal list of causes of death that was acceptable to everyone. Medical training differed from country to country, and so did the definitions of diseases and causes of death. The cholera epidemic and other waves of disease induced governments to seek harmonisation of medical nomenclature. Mortality development was of crucial importance to life insurance companies, too. They required reliable mortality tables but also needed to be able to assess risk by population group and life circumstances.

Sanitarians like Villermé in France and reformers like Chadwick in Britain cranked up the public debate on causes of death. Like so many of their contemporaries, they were painfully aware of the fact that average life expectancy was approximately 35 years. They also knew that there were wide variations between countries and enormous disparities between industrial cities and the countryside. They were deeply committed to a state role - however limited - in regulating social life. Government was the institution that was best able to alleviate the poverty and suffering that contributed to the high mortality rate among some population groups. This position transformed the debate on causes of death into a political issue that the international statistical congress was ill-equipped to handle. The statisticians were not opposed to collecting data on death and disease, but many were averse to every form of government intervention ensuing from statistical research.

They preferred to restrict their discussion of mortality to the nomenclature of the causes of death, a difficult enough subject in its own right. Three lists were in circulation: one compiled by the British sanitarian William Farr, head of the statistical department of the General Register Office, one by Marc d'Espine, a physician from Geneva, and a compromise list that had been put forward at the Paris congress. The Vienna preparatory commission produced a fourth list, in which no distinction was made between acute and chronic diseases leading to death (as d'Espine had proposed) nor between infectious, constitutional and local diseases (as in Farr's list). Other important issues included the determination of death as such (the fear of being buried while still alive was widespread) and an official death certificate, preferably drawn up by the attending doctor. The death certificate was to state whether the fatal illness had been acute or chronic, and epidemic or sporadic. It was acknowledged, though, that there would not always be a doctor in attendance to determine death and establish the cause of death.

The preparatory sessions attended by the medical statistics specialists were lively gatherings, and confirmed that the statistics of death were dealt with very differently from country to country. The experts ultimately agreed on a nomenclature that distinguished the following causes of death: stillbirth, congenital defects (causing death in the first week), old age (after age 60), violence, disease and unknown causes. They also spoke at length about making post-mortem examination a common practice everywhere, and the possibility of having physicians conduct them as a matter of course. The post-mortem had been widely introduced to prevent live burials. The statisticians saw this practice as 
an opportunity to learn more about the causes of death in general, but clearly there were too few doctors for the post-mortem examination to be a statistical instrument. Once again, their desire to quantify and create order overrode their sense of reality.

The plenary discussion focused on establishing medical statistics bureaux to process the information on the death certificate. The Frenchman Legoyt was concerned about high costs and preferred to see physicians assigned to existing statistical bureaus. He thought most of the work could be done by nonpractitioners. Farr disputed this on the grounds of his experience in Britain, but confirmed that a single physician could process the death certificates of an entire country. The proposal that was adopted in the end did not specify how statistics pertaining to cause of death should be processed. This compromise was hardly conducive to standardisation.

Industrial statistics had been a regular item on the congress agenda since 1853 , but thus far no agreement had been reached on a joint approach. In every country attempts had been made to conduct industrial counts but it was not unusual for one count to deviate significantly from another. Industrial development was moving full steam ahead. The nomenclature of French industrial statistics changed considerably between the periods of 1839-1847 and 18601865. The matter was rendered more complicated by the preference some economists had for incorporating labour statistics into industrial statistics. If they had their way, questions about female and child labour, wages, working conditions and living standards would have to be included. This posed an obvious problem, as it would allow social issues to be surreptitiously slipped into the statistics.

When Czoernig tabled industrial statistics again in 1857, he tried to marginalise the labour factor. He concentrated almost exclusively on production statistics. That is how he had dealt with Austria's industrial statistics in the Tafeln since 1845 , how he had built up a degree of trust among entrepreneurs and how he intended to win over the international community. He told the congress that the greatest challenge of industrial statistics was the classification of products and industrial activity, a theme on which no agreement had been reached at the world's fairs in London and Paris. By proposing an extremely precise classification system for industrial goods (34 classes and 185 subcategories), he diverted attention from the workers and their circumstances, and expunged a thorny political issue.

Czoernig may not have been consciously motivated by strategic, political considerations, but rather by the complexity of this research area. In statistical terms, the numbers of workers, the ratio of men to women and children and working hours were not controversial. Whether the minimum working age was 14 or 16 years was seen as a relatively simple matter of measurement, not a social issue. Much more difficult - and therefore much more appealing and relevant - was the matter of classifying industrial products and distinguishing between raw materials, semi-manufactures and end products.

There were plenty of obstacles for the true statistician. The industrial statistics 
rapporteurs were Ernst Engel, director of the Saxony statistical bureau, and Auguste Visschers, member of the Belgian Central Commission for Statistics. Visschers, who had stepped into the breach for workers' budgets in 1853, was consumed by classification and information collection methods. He posed no major objections, but emphasised the importance of accurate bureaucratic control. Czoernig found in Engel a kindred spirit, who was in no small way obsessed with the direct transmission of reality in numbers. It was not merely by chance that Ernst Engel, whose later activities as director of Prussian statistics are described in detail further on in this book, gave serious consideration to the definition of industry (Gewerbe): 'Who would be able to keep a tally of the industrial labours of all people and discover every room where spinning, knitting, sewing, carving, washing or ironing takes place?'23 And how should manufacturing be distinguished from craftwork? Inevitably, arbitrary choices would have to be made, a task to which the statistician was well suited.

Of even greater interest to statisticians in 1857 was the exchange of ideas regarding data collection methods. A classic problem was the reluctance of industrial producers to furnish reliable numbers. To make matters worse, it was virtually impossible to acquire and process information about every single business in every part of the country. Czoernig had introduced the 'combination' method to deal with this problem. It was a mathematical trick for calculating large unknown quantities similar to probability calculation:

For the statistician who studies situations that change every day, there is no absolute truth; he must seek the truth in approximation. If the approximation is based on precisely defined elements applied in the right combination, and thus succeeds, it will render the relationship under investigation in such a way that statistical conclusions may be drawn from it and produce the only possible expression, within a given period, of continually mutating facts. ${ }^{24}$

Engel delved more deeply into the 'combination' method, which he defined as follows: 'inferring small quantities that resist observation and measurement from a larger number of measured and observed quantities. He emphasised that this was not 'conjectural statistics', probability or even what would now be called extrapolation. In the world of administrative statistics such methods were out of the question. The larger quantity had to be measured first, and statisticians could play only with the resulting hard numbers. Still, this did not prevent the value of 'combined' numbers being called into question. Some believed that if civil servants began applying 'subjective' criteria their credibility would be undermined. Others were of the opinion 'that the combination method of completion through inference of the small from the much larger was not subjective, but rather the result of calculation, and was therefore justified in claiming credibility, especially if a detailed explanation of the calculation process was given in each case, as had been proposed.. ${ }^{25}$

This compromise was particularly popular among government representatives. In the 1850s government statistics was still influenced by the Napoleonic tradition of 'good administration', grounded in reliable, comprehensive statistics. 
Only full knowledge based on hard numbers would suffice. The power of the number was absolute. Or as Engel remarked during the debate: 'as the culture of material interests moves to the foreground in our time, governments and the governed will have an ever increasing need to express the significance of this culture in numbers. ${ }^{26}$

As it turned out, the statisticians had difficulty seeing the implications of 'expressing culture in numbers.' Causes of death, industry and the other themes on the agenda all brought the same dilemmas to light. Efforts towards completeness were impeded at every turn. And when practical barriers were lifted, they were replaced by ideological or political obstacles, particularly if agreement had to be reached internationally.

The Austrian trade minister, Georg Ritter von Toggenburg, had called upon the German-speaking statisticians to enter into a closer cooperative relationship. Karl Joseph Kreutzberg, chairman of the Prague trade association, filed a motion proposing the establishment of a German Centralverein für Statistik and a journal. He wanted to discuss his proposal in detail in one of the sessions, and explained that statistics, in his view, should be more than just an instrument of the state, but also 'a public good of the nation'. What Kreutzberg had in mind was a grossdeutsch nation: 'There is a great power that stretches from the Baltic coast to the Adriatic Sea: it is the power of the German spirit.' He continued: 'There is a heavenly body that we gaze upon in Germany, in the high mountains and in the Taunus range, on the banks of the Danube and the mouth of the Elbe, and it is German research.' And to press home the point: 'There is a cathedral being built by the same method everywhere, in Göttingen and in Graz, in Königsberg and in Freiburg, and it is German science. ${ }^{27}$

Louis Wolowski, a member of the Institut de France, gave a predictable response. An international congress was no place for a debate on a grossdeutsch unification. Czoernig, too, would have preferred to call the proposal out of order. But Kreutzberg wanted to bring his motion to a vote come what may, and the chairman could not refuse. Most participants with a vote were against the motion, so further discussion of the proposal was ruled out. Engel tried to salvage the situation by remarking that 'in accordance with German parliamentary procedure' a minority of at least twelve proponents was sufficient to pass a motion. Czoernig pointed out that the congress rules did not permit this procedure.

The representatives of the statistical bureaux of the German states, including Professor Friedrich Wilhelm Schubert of Prussia, decided to stay two days longer and meet separately on 7 September - after the official closing of the congress - to discuss whether a statistics association and a statistics journal were feasible for Grossdeutschland. Back in 1846 Freiherr von Reden had set up a general German statistics periodical, but his initiative died a premature death when publication was suspended during the revolutionary strife of 1848 . The intellectual objectives of the German statistical partnership were largely the same as those of the international statistical congress, but given the common 
language and existing agreements (particularly the toll treaties) between the German states it seemed simpler to establish a concrete voluntary agreement than to impose uniformisation. They discussed setting up an official association of statistical bureaux, using common forms, instituting a regular exchange of documents, publishing a German statistics annual and maintaining a statistical bibliography.

As logical as this course of action seemed, the German statisticians were unable to reach concrete agreements. They parted promising to inform their respective governments of the initiative. This had become common practice at the international congresses, and it proved equally unsuccessful for the German statisticians. Grossdeutsch statistics would not become a reality until Kaiser Wilhelm I and Otto von Bismarck deployed the Prussian armies and brought about German unity. By then, Austria's role was over.

The preparatory commission arranged two post-congress river cruises, one on the Semmering and one on the Danube to Pressburg in Bratislava. Apparently, during these outings the gentlemen discussed topics that they had not dared to broach even in the corridors of the Austrian House of Representatives. They talked about women and mathematics, and about Julia, Duchess of Giovane, probably the first woman statistician. In 1796 she published her Plan pour faire servir les voyages à la culture des jeunes gens qui se vouent au service de l'Etat dans la carrière politique, accompagné d'une table pour faciliter les observations statistiques et politiques et de lesquisse d'une carte statistique. Remarkably, this seems to sum up nineteenth-century statistics.

The third international statistical congress in Vienna continued along the course set by the Paris congress. As before, the preparatory commission put several topics on the agenda which received special attention from the assembled statisticians. The advantage of this procedure was that it precluded the need to address the entire international statistics project. On the other hand, it gave Austria the power to set the agenda, which it did. The dominance of the Austrian contribution was also evident from the list of participants, most of whom hailed from the Habsburg monarchy. As a result, the Austrian style of practicing statistics was very apparent and statistics was identified much more closely with the state than it had been at the Belgian and French congresses.

Czoernig, the undisputed leader of Austrian government statistics, was the ideal advocate of neo-absolutist statistics. He could circumvent politically sensitive subjects with ease or obfuscate them with technocratic deliberations. To him, professionalism was a matter of administrative perfection; politics seemed to be secondary. But he was also conciliatory, and a man of imagination who spoke several languages. These were talents that served him well in the international milieu. He remained at the helm of Austrian statistics until 1865. In 1863 he was appointed the first chairman of the Statistische Zentralkommission and in 1864 he launched a statistics seminar for civil servants, after the Prussian example. The international congress saw at least one of its wishes fulfilled when the central commission was established. 


\section{Notes}

1 L. von Ranke, 'An Clara Ranke (Brussels, 22 September 1853)', in W.P. Fuchs (ed.), Das Briefwerk (Hamburg 1949), p. 373.

2 In 1898 the painting was still part of the municipal collection. During the First World War it disappeared. It may have been stolen by the German occupying forces, who used the Louvain city hall as their headquarters (information by Veronique Vandekerchove, curator of the Museum Vander Kelen-Mertens in Louvain).

3 'Carl Freiherr von Czörnig', Statistische Monatsschrift 15 (1889), 546.

4 Generallandesarchiv Karlsruhe, Abt. 237, Finanz Ministerium, no. 7119, report by Volz, 31 December 1835.

5 Letter from Emperor Francis I to Anton Freiherr von Baldacci, 6 April 1829, cited in Denkschrift der k.k. statistischen Zentralkommission zur ihrer fünfzigjährigen Bestandes (Vienna 1913), p. 12.

6 Karl Freiherr von Czoernig, 'Bericht über den Entwurf eines Programmes für die dritte Versammlung des internationalen statistischen Congresses', in Rechenschafts-Bericht über die dritte Versammlung des internationalen Congresses für Statistik abgehalten zu Wien vom 31. August bis 5. September 1857 (Vienna 1858), p. 12.

7 C. von Czoernig, Oesterreich's Neugestaltung 1848-1858 (Stuttgart and Augsburg 1858), pp. 17-18.

8 Pál Hunfalvy, Magyarország ethnographiája (Budapest 1876), also published in German in 1877, see Z. Tóth, 'Liberale Auffassung der Ethnizität in der "Ethnographie von Ungarn" von Pál Hunfalvy', in C. Kiss, E. Kiss and J. Stagl (eds), Nation und Nationalismus in wissenschaftlichen Standardwerken Österreich-Ungarns, ca. 1867-1918 (Vienna 1997), pp. 57-64.

9 GStA PK, I. Hauptabteilung, Repositur 77, Ministerium des Innern, Abteilung I, Section 13, Nr. 99, Bd. 1 Statistische Generalversammlungen des In- und Auslandes (1853-1859), letter from Dieterici to the Ministry of the Interior, Berlin, 25 March 1857.

10 C. von Czoernig, 'Statistik der ethnographischen Verschiedenheiten eines Staates. Bericht', in Rechenschafts-Bericht über die dritte Versammlung des internationalen Congresses für Statistik, p. 207.

11 Ibid., p. 208.

12 M. Labbé, 'Le projet d'une statistique des nationalités discuté dans les sessions du Congrès International de Statistique (1853-1876)', in H. le Bras, F. Ronsin, E. Zucker-Rouvillois, Démographie et Politique (Dijon 1997), pp. 127-142.

13 G. Palsky, Des chiffres et des cartes. Naissance et développement de la cartographie quantitative française au XIXe siècle (Paris 1996), pp. 53-56.

14 F. Ritter von Hauslab, 'Anwendung der Kartographie und der Graphik überhaupt auf die Zwecke der Statistik', in Rechenschafts-Bericht über die dritte Versammlung des internationalen Congresses für Statistik, p. 202.

15 Rechenschafts-Bericht über die dritte Versammlung des internationalen Congresses für Statistik, p. 428; also observed in the report of A. Ficker, 'Die dritte Versammlung des internationalen Congresses für Statistik zu Wien om september 1857', Mittheilungen aus dem Gebiete der Statistik 6:3 (1857), 134.

16 Rechenschafts-Berichtüber über die dritte Versammlung des internationalen Congresses für Statistik, p. 548.

17 E. Brian, 'Observations sur les origines et sur les activités du congrès international de statistique (1853-1876)', Bulletin de l'Institut International de Statistique. Actes de la 47ème session, Tome LIII, Livraison I (Paris 1989), 127.

18 Cited from the Quarterly Journal in A. Ficker, 'Die dritte Versammlung', p. 48.

19 C. Freiherr von Czoernig, Systematische Darstellung der Budgets von Grossbritannien (1862), 
Frankreich (1862) und Preussen (1861), nebst einer Uebersicht der Budgets von Baiern, Belgien, den Niederlanden, Portugal, Spanien und Russland (Vienna 1862), p. 4.

20 Ibidem, vii-viii.

21 F. van der Woude, Minister Mr. P.P. van Bosse en de fiscale wetgeving rond het midden van de $19 e$ eeuw (Ph.D. dissertation, Rijksuniversiteit Groningen 1997), p. 85. I should like to thank Christianne Smit for this piece of information.

22 Rechenschafts-Bericht über die dritte Versammlung des internationalen Congresses für Statistik, pp. 15-16.

23 Ibid., p. 288.

24 Ibid., p. 149.

25 Ibid., pp. 290-291.

26 Ibid., p. 283.

27 Ibid., p. 270. 